\title{
Hubungan Kadar Kalsium Dalam ASI, PASI Dan MPASI dari Asupan Bayi dengan Panjang Badan Bayi Usia 6-12 Bulan di Wilayah Kerja Puskesmas Lubuk Buaya Padang 2017
}

\author{
Chyka Febria $^{1}$, Masrul $^{2}$, Eva Chundrayetti ${ }^{3}$
}

\section{Abstrak}

Survei awal yang dilakukan di Wilayah Kerja Puskesmas Lubuk Buaya Padang, dari sepuluh bayi diukur panjang badannya didapatkan empat bayi yang mengalami stunting, sedangkan prevalensi pemberian ASI ekslusif di wilayah tersebut cukup tinggi yaitu $54,66 \%$. Tujuan penelitian ini adalah menentukan hubungan kadar kalsium dalam ASI, PASI dan MPASI terhadap panjang badan bayi usia 6-12 bulan di wilayah kerja Puskesmas Lubuk Buaya Padang 2017. Penelitian ini telah dilakukan di wilayah kerja Puskesmas Lubuk Buaya Padang. Waktu penelitian telah dimulai dari bulan januari 2017 sampai Agustus 2017. Desain penelitian yang digunakan cross sectional dengan jumlah sampel 83 orang. Pengambilan sampel dilakukan secara simple random sampling. Data dianalisis secara univariat dan bivariat dengan menggunakan uji korelasi pearson. Pemeriksaan kadar kalsium dalam ASI, PASI dan MPASI dari makanan yang dimakan sehari-hari (ASI, PASI dan MPASI) dengan menggunakan AAS (Atomic Absorption Spectrophotometer). Berdasarkan hasil penelitian, didapatkan bahwa rerata kadar kalsium dalam tubuh bayi usia 6-12 bulan adalah $125,4 \mathrm{mg} / 100 \mathrm{ml} \pm 29,12$, rerata panjang badan bayi usia 6-12 bulan adalah 68,20 $\mathrm{cm} \pm 2,371$. Pada uji korelasi, didapatkan korelasi lemah antara kadar kalsium dalam ASI, PASI dan MPASI dengan panjang badan bayi usia 6-12 bulan ( $r=0,045)$. Disimpulkan bahwa belum ditemukan korelasi antara kadar kalsium dalam ASI, PASI dan MPASI dalam intake bayi dengan panjang badan bayi usia 6-12 bulan.

Kata kunci: kadar kalsium dalam ASI, PASI dan MPASI dari asupan bayi, panjang badan bayi

\section{Abstract}

The preliminary survey was conducted in the working area of Lubuk Buaya Padang health center, among 10 babies, there were four of them who had stunting, while the prevalence of exclusive breastfeeding in the region is quite high at $54.66 \%$. The objective of this study was to determine the relationship between water content in the body of infants and long-term age of 6-12 months in the working area Puskesmas Lubuk Buaya Padang 2017. This research had been conducted in the Work Area of Lubuk Buaya Padang Health Center. The study had been started from January 2017 to August 2017. The study design used cross sectional with a sample size of 83 people. Sampling was done by simple random sampling. Data were analyzed by univariate and bivariate using test. Examination of calcium levels in the baby's body from food eaten daily using AAS (Atomic Absorption Spectrophotometer). Based on the results of the study, the average calcium intake breast milk, breast milk substitutes and complementary foods with long earth body 6-12 month aged 6-12 months was $125.4 \mathrm{mg} / 100 \mathrm{ml} \pm 29.12$, the average body length of 6-12 months was $68.20 \mathrm{~cm} \pm 2.371$. In the trial, obtained a weak level between the level of content in the baby's body with a longterm age of 6-12 months $(r=0.045)$. It can be concluded there is no significant relationship between calcium intake breast milk, breast milk substitutes and complementary foods with long earth body 6-12 month aged 6 -12 months.

Keywords: infant calcium intake breast milk, breast milk substitutes and complementary foods infant body length 
Affiliasi penulis: 1. Prodi Magister S2 Biomedik FK Unand (Fakultas Kedokteran Universitas Andalas Padang), 2. Bagian Gizi FK Unand, 3. Bagian Anak FK Unand/ RSUP Dr M.DJamil Padang Korespondensi: Chyka Febria. Email: chykafebria91@gmail.com Telp: 082285878001

\section{PENDAHULUAN}

Gizi merupakan salah satu faktor penting yang menentukan tingkat kesehatan dan kesejahteraan manusia. Gizi yang baik jika terdapat keseimbangan dan keserasian antara perkembangan fisik dan perkembangan mental orang tersebut. Terdapat kaitan yang sangat erat antara status gizi dan konsumsi makanan. Tingkat status gizi optimal akan tercapai apabila kebutuhan zat gizi optimal terpenuhi. ${ }^{1}$

Global Strategy for Infant and Young Child Feeding, WHO/UNICEF merekomendasikan hal yang penting dalam mencapai tumbuh kembang yang optimal yaitu: memberikan bayi ASI sesegera mungkin, bayi ASI ekslusif dan memberikan MPASI bayi usia 6 bulan keatas serta melanjutkan ASI sampai usia 24 bulan. Hal tersebut menekankan secara sosial budaya MP-ASI hendaknya dibuat dari bahan yang murah dan mudah diperoleh dari daerah setempat. ${ }^{2.3}$

Stunting merupakan masalah gizi utama yang terjadi pada Negara berkembang. UNICEF mengemukakan sekitar $80 \%$ anak stunting terdapatdi 24 negara berkembang di Asia dan Afrika. Indonesia merupakan negara urutan kelima yang memiliki prevalensi anak stunting tertinggi setelah India, China, Nigeria dan Pakistan. Saat ini, prevalensi anak stunting di bawah 5 tahun di Asia Selatan sekitar $38 \%{ }^{4}$

Riset Kesehatan Dasar (Riskesdas) tahun 2013 mencatat prevalensi stunting Nasional mencapai $37,2 \%$, meningkat dari tahun 2010 (35,6\%) dan 2007 $(36,8 \%)$. Artinya, pertumbuhan tidak maksimal diderita oleh sekitar 8 juta anak Indonesia, atau satu dari tiga anak Indonesia. Prevalensi stunting di Indonesia lebih tinggi dari pada negara-negara lain di Asia Tenggara, seperti Myanmar (35\%), Vietnam (23\%) dan Thailand $(16 \%){ }^{5}$
Di Sumatera Barat pada tahun 2013 prevalensi stunting sebesar $29,3 \%{ }^{6}$ Dari survei awal yang dilakukan di wilayah kerja Puskesmas Lubuk Buaya Padang, dari sepuluh bayi diukur panjang badannya didapatkan empat bayi yang mengalami stunting, sedangkan prevalensi pemberian ASI di wilayah tersebut cukup tinggi.

\section{METODE}

Desain penelitian ini adalah cross sectional yang bertujuan menentukan hubungan antara kadar kalsium dalam ASI, PASI dan MPASI dari asupan bayi terhadap panjang badan bayi. Pengukuran terhadap variabel bebas dan variabel terikat dilakukan sekali dan dalam waktu yang bersamaan.

HASIL

Rata-Rata Kadar Kalsium dalam ASI, PASI dan MPASI dalam intake bayi

Tabel 1. Rerata kadar kalsium dalam ASI, PASI dan mpasi dari asupan bayi

\begin{tabular}{|c|c|c|c|}
\hline Variabel & Rerata $\pm S D$ & Min & Maks \\
\hline $\begin{array}{l}\text { Kadar kalsium dalam } \\
\text { ASI, PASI dan MPASI } \\
\text { dari asupan bayi } \\
(\mathrm{mg} / 100 \mathrm{ml})\end{array}$ & $125,4 \pm 29,12$ & 67,65 & 209,06 \\
\hline
\end{tabular}

Berdasarkan Tabel 1, dapat dilihat bahwa rerata kadar kalsium dalam ASI, PASI dan MPASI dari asupan bayi adalah 125,4 mg/100 $\mathrm{ml} \pm 29,12$.

\section{Uji Normalitas}

Setelah dilakukan uji normalitas data dengan menggunakan uji Kolmogorov Smirnov, untuk mengetahui distribusi data pada penelitan ini. Dalam penelitian ini ditemukan data kadar kalsium dalam tubuh bayi dan panjang badan bayi usia $6-12$ bulan terdistribusi normal $(p>0,05)$. Selanjutnya untuk melihat hubungan kadar kalsium dalam tubuh bayi dengan panjang badan bayi usia 6-12 bulan digunakan Uji Korelasi Pearson. 
Tabel 2. Hubungan kadar kalsium dalam ASI, PASI dan MPASI dari asupan bayi dengan panjang badan bayi usia 6-12 bulan

\begin{tabular}{|c|c|c|c|}
\hline & \multirow[t]{2}{*}{ Variabel } & \multicolumn{2}{|c|}{$\begin{array}{l}\text { Panjang badan bayi usia } \\
6-12 \text { bulan (gr) }\end{array}$} \\
\hline & & $\mathbf{R}$ & $p$ \\
\hline - & 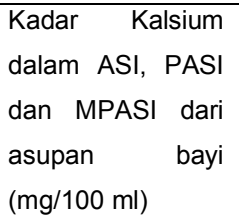 & 0,045 & 0,686 \\
\hline
\end{tabular}

Berdasarkan Tabel 2 dapat dilihat bahwa korelasi kadar kalsium dalam ASI, PASI dan MPASI dari asupan bayi dengan panjang badan bayi usia 612 bulan sebesar $(r=0,045)$. Terdapat korelasi lemah dan hasil yang didapatkan tidak signifikan antara kada kalsium dalam tubuh bayi dengan panjang badan bayi usia $6-12$ bulan $(p>0,05)$.

Tabel 3. Hubungan kadar kalsium dalam ASI, PASI dan MPASI dari asupan bayi dengan panjang badan bayi usia 6-12 bulan.

\begin{tabular}{lccc}
\hline & & $\begin{array}{c}\text { kalsium dalam } \\
\text { ASI, PASI dan } \\
\text { MPASI }\end{array}$ & $\begin{array}{c}\text { Panjang } \\
\text { Badan bayi }\end{array}$ \\
\hline $\begin{array}{lcc}\text { kalsium dalam } \\
\text { ASI, PASI dan }\end{array}$ & $\begin{array}{c}\text { Correlation } \\
\text { MPASI }\end{array}$ & 1 & .045 \\
& $\mathrm{p}$ & & .686 \\
Panjang Badan Pearson & $\mathrm{n}$ & 83 & 83 \\
Bayi & Correlation & .045 & 1 \\
$\mathrm{p}$ & .686 & \\
& $\mathrm{n}$ & 83 & 83 \\
\hline
\end{tabular}

Perbedaan rata-rata kadar kalsium ASI, PASI dan MPASI dari asupan bayi antara bayi yang stunting dengan normal

Pada Tabel 4 dapat dilihat bahwa dari 83 sampel terdapat 14 orang bayi $(16,86 \%)$ yang mengalami stunting dengan rerata kadar kalsium $121,95 \pm 25,77$ dan sedangkan yang tidak stunting (normal) didapatkan sebanyak 69 orang bayi yang tidak stunting dengan rerata kadar kalsium 126,12 \pm 29,88 .
Tabel 4. Perbedaan rerata kadar kalsium ASI, PASI dan MPASI dari asupan bayi antara bayi yang stunting dengan yang normal

\begin{tabular}{|c|c|c|c|}
\hline $\begin{array}{c}\text { Panjang Badan } \\
\text { bayi }\end{array}$ & $\begin{array}{c}\text { Kadar Kalsium } \\
\text { ASI, PASI dan } \\
\text { MPASI asupan } \\
\text { bayi } \\
\text { Mean } \pm S D\end{array}$ & $p$ & $\mathbf{N}$ \\
\hline $\begin{array}{ll}- & \text { Normal } \\
- & \text { Stunting }\end{array}$ & $\begin{array}{r}126,12 \pm 29,88 \\
121,95 \pm 25,77\end{array}$ & 0,628 & $\begin{array}{l}69 \\
14\end{array}$ \\
\hline
\end{tabular}

\section{PEMBAHASAN}

\section{Karakteristik Subjek Penelitian}

Karakteristik responden terdiri dari umur ibu, pendidikan dan pekerjaan ibu. Umur ibu berada dalam umur reproduksi sehat. Tingkat pendidikan ibu tergolong sedang pendidikan rerata SMA/SMK. Ibu kebanyakan tidak bekerja atau ibu rumah tangga sehingga perolehan penghasilan pada umumnya bersumber dari bapak (suami).

Rerata panjang badan lahir bayi adalah 48,4 $\mathrm{cm} \pm 1,68$, panjang badan merupakan salah satu indikator kesehatan bayi baru lahir (BBL). Rerata panjang badan bayi baru lahir dalam penelitian ini berada dalam kisaran normal, saat baru lahir, panjang badan normal bayi adalah $45 \mathrm{~cm}-55 \mathrm{~cm}^{7}$

Pada penelitian ini ditemukan rerata kadar kalsium dalam tubuh bayi adalah $125,4 \mathrm{mg} / 100 \mathrm{ml} \pm$ 29,12. Berdasarkan penelitian Jarjou et al (2011), bahwa rerata kadar kalsium dalam ASI 179 mg/100 ml \pm 53. Sedangkan menurut penelitian Chaidir et al, rerata kadar kalsium dalam ASI lebih tinggi 344,25 $\mathrm{mg} / 100 \mathrm{ml} \pm 82,78$. Berdasarkan penelitian Kurniasari (2016), berdasarkan penelitian ini bahwa memang terdapat kasium rendah pada anak yang mengalami stunting. Didapatkan rerata kadar kalsium serum pada anak stunting sebesar $12,14 \pm 1,97 \mathrm{mg} / \mathrm{l}$. ${ }^{7.8 .9}$

Tinggi Badan (TB) atau merupakan parameter paling penting bagi keadaan yang telah lalu dan keadaan sekarang, jika umur tidak diketahui dengan tepat. Tinggi badan juga merupakan ukuran kedua yang penting, karena dengan menghubungkan berat badan terhadap tinggi badan (quac stick) faktor umur dapat dikesampingkan. Tinggi badan untuk anak kurang dari 2 tahun sering disebut dengan panjang badan (Supariasa, 2012). ${ }^{10}$ 
Korelasi kadar kalsium dalam ASI, PASI dan MPASI intake bayi dengan panjang badan bayi usia 6-12 bulan

Hasil penelitian ini menunjukkan korelasi lemah $r=0,045$, berdasarkan uji statistik, hasil yang didapatkan adalah tidak signifikan antara kadar kalsium dalam tubuh bayi dengan panjang badan bayi usia 6-12 bulan ( $p>0,05)$.

Hal ini sama dengan penelitian Hardinsyah, (2008) yang menyebutkan bahwa tidak ada hubungan yang nyata antara kalsium dari susu dengan tinggi badan. Hal itu karena selain kalsium, faktor yang mempengaruhi tinggi badan yaitu hormon pertumbuhan, IGF-I, faktor genetik, aktivitas harian dan olahraga. Dalam penelitian ini, justru tidak didapat hubungan genetik (tinggi badan orang tua) dengan tinggi badan anak. ${ }^{11}$

Rendahnya asupan kalsium bisa berdampak buruk terhadap kesehatan, terutama masalah pertumbuhan dan masalah kesehatan lain yang berhubungan dengan fungsi kalsium dalam tubuh. Kalsium merupakan komponen terbesar dalam tulang, sehingga asupan kalsium dari makanan penting untuk meningkatkan penambahan kekuatan dan kesehatan tulang. $^{12}$

Penelitian yang dilakukan Endika (2011). Bahwa dari total sampel yang diteliti sebanyak 30 orang, 15 sampel menyusui secara ekslusif dan 15 sampel mendapat susu dari susu formula, hasil pengujian data untuk pertambahan panjang badan bayi usia 4-6 bulan antara bayi yang diberikan ASI eklsusif dan susu formula menggunakan uji statistik independent-test menunjukkan nilai $p=0,355(p>0,05)$. Tidak ada perbedaan pertambahan panjang badan antara bayi yang menyusui secara ekslusif dan susu formula. $^{13}$

Berdasarkan penelitian Saptawati (2014), bahwa didapatkan $15,7 \%$ subjek penelitian mengalami stunting, lebih dari $80 \%$ subjek penelitian memiliki asupan harian kalsium yang rendah dan tidak ditemukan korelasi antara asupan kalsium dengan indikator tinggi badan. ${ }^{14}$

Pada penelitian ini ditemukan bahwa kadar kalsium dalam tubuh bayi hanya berkontribusi $0,2 \%$ terhadap panjang badan bayi usia 6-12 bulan dan $99,8 \%$ dari faktor lain yang tidak diteliti, panjang badan juga merupakan multifaktor. Panjang badan merupakan indikator pertumbuhan yang secara bersama-sama dapat menggambarkan pertumbuhan seseorang. Faktor yang dominan yang juga berpengaruh terhadap panjang badan adalah tinggi badan orang tua dan asupan. Panjang badan lahir mempengaruhi pertambahan panjang badan bayi. Seseorang yang memiliki orang tua yang tinggi akan memiliki tinggi badan lebih tinggi dari mereka yang orang tua nya pendek. Begitu juga dengan asupan, tidak hanya kalsium yang mempengaruhi panjang badan, tetapi zat gizi lain seperti karbohidrat, protein dan lemak serta vitamin dan mineral lainnya jika dikonsumsi secara adekuat akan mampu mengoptimalkan tinggi badan seseorang. ${ }^{15}$

\section{Rerata kadar kalsium antara bayi yang stunting dengan yang tidak stunting}

Hasil penelitian ini dapat dilihat bahwa dari 83 sampel terdapat 14 orang bayi $(16,86 \%)$ yang mengalami stunting dengan rerata kadar kalsium $121,95 \pm 25,77$ dan sedangkan yang tidak stunting (normal) didapatkan sebanyak 69 orang bayi yang tidak stunting dengan rerata kadar kalsium 126,12 \pm 29,88 .

Sejalan dengan penelitian sebelumnya bahwa asupan kalsium lebih rendah pada anak stunting dibandingkan anak tidak stunting. Ketika anak dengan riwayat BBLR dieklusi, maka asupan kalsium, vitamin D dan riboflavin significan lebih rendah pada anak stunting. Risiko stunting 3,93 kali lebih besar pada balita dengan asupan kalsium rendah. Sumber kalsium utama adalah susu dan hasil susu, selain itu ikan dan makanan sumber laut juga mengandung kalsium lebih banyak dibandingkan daging sapi maupun ayam. Kebiasaan anak dalam mengkonsumsi susu memberikan sumbangan kalsium yang cukup. Anak stunting mengkonsumsi kalsium dari susu signifikan lebih rendah dari pada anak tidak stunting, dengan rata-rata $276,17 \mathrm{mg} /$ hari pada anak stunting dan $628,41 \mathrm{mg} /$ hari pada anak tidak stunting.

Konsentrasi kalsium dalam plasma terutama ion kalsium bebas sangat hati-hati dipertahankan sedemikian rupa untuk transmisi impuls saraf dan kontraksi otot, serta sebagai katalisator berbagai reaksi biologik, seperti absorbs vitamin B12, tindakan 
enzim pemecah lemak, lipase pancreas, sekskresi insulin oleh pancreas, pembentukan dan pemecahan asetilkolin. Homoestatis kalsium diatur terutama melalui system hormonal terpadu yang mengontrol transportasi kalsium dalam usus, ginjal dan tulang. Proses ini melibat kan dua calcium regulating hormone besar dan reseptornya yaitu PTH dan reseptor PTH, dan 1,25 $(\mathrm{OH}) 2 \mathrm{D}$ dan reseptor vitamin $\mathrm{D}$, serta serum terionisasi kalsium dan calcium-sensing receptor. Homeostatis serum kalsium berkembang untuk mempertahankan kadar ion kalsium di ekstraseluler dalam rentang normal dengan mengalirkan kalsium dari cadangan ke tulang. ${ }^{11}$

Selama pertumbuhan, tuntunan terhadap mineralisasi tulang sangat tinggi, asupan kalsium yang sangan rendah dapat menyebabkan hipokalsemia, meskipun sekresi dari kelenjar paratiroid maksimal, yang dapat mengakibatkan rendahnya mineralisasi matriks deposit tulang baru dan disgungsi osteoblas. Defisiensi kalsium akan mempengaruhi pertumbuhan linear jika kandungan kalsium dalam tulang kurang dari 50\% kandungan normal. Pada bayi, kekurangan kalsium didalam tulang dapat menyebabkan rakitis, sedangkan pada anak-anak, kekurangan deposit dapat menyebabkan terhambatnya pertumbuhan. ${ }^{12}$

\section{SIMPULAN}

Tidak terdapat korelasi antara kadar kalsium dalam ASI, PASI dan MPASI terhadap panjang badan bayi usia 6-12 bulan.

\section{UCAPAN TERIMA KASIH}

Terima kasih kepada Kepala dan Staf Puskesmas Lubuk Buaya Padang serta Bidan desa dan Kader setiap wilayah kerja dan laboratorium Laboratorium Terpadu Kopertis Wilayah $\mathrm{X}$ yang telah membantu pemeriksaan sampel.

\section{DAFTAR PUSTAKA}

1. Moehji S. IImu Gizi 2, Penanggulangan Gizi Buruk. Papas Sinar Sinanti. Jakarta; 2013.

2. WHO, UNICEF. Global Strategy for Infant and Young Child Feeding. Geneva: World Health Organization; 2003.

3. Al-Rahmad AH. Kajian stunting pada anak balita ditinjau dari pemberian ASI ekslusif, MP-ASI, status imunisasi dan karakteristik keluarga di kota Banda Aceh. Jurnal Kesehatan Indonesia. 2010; 01:65-70.

4. UNICEF. Prevalensi stunting di 24 Negara Asia Afrika, salah satunya Indonesia; UNICEF; 2014

5. Riskesdas. Prevalensi stunting nasional mulai dari tahun 2007, 2010 dan 2013; 2013.

6. Dinas Kesehatan Sumbar. Prevalensi stunting pada tahun 2013 di Sumatera Barat sebesar 29,3\%; 2014

7. Jarjou LMA, Goldberg G R, Coward W A, Prentice A. Calcium intake of rural Gambian infants: a quantitative study of the relative contributions of breast milk and complementary foods at 3 and 12 month of age. Europe Journal Of Clinical Nutrition; 2012; 66:673-7.

8. Chaidir MM, Citrakesumasari, Devintha V. Konsentrasi mikronutrien kalsium (Ca) pada ASI berdasarkan determinan ibu dan bayi di Puskesmas Kassi-Kassi (tesis). Makassar: Program Studi IImu Gizi Fakultas Kesehatan Masyarakat Universitas Hasanuddin; 2015.

9. Kurniasari Y. Kadar kalsium serum pada anak stunting dan tidak stunting usia 24-59 bulan (tesis). Bandung: Magister Kebidanan Universitas Padjajaran; 2016.

10. Supriasa. Pertumbuhan parameter pada bayi dan anak balita. Jurnal Gizi Klinik Indonesia. 2012; 01:45-60.

11. Hardinsyah. Hubungan kalsium dalam susu dengan tinggi badan anak. Jurnal Kesehatan Indonesia. 2008;02:54-8. 
12. Krummel. Pentingnya asupan kalsium bagi bayi dalam 1000 hari pertama kehidupan. Jurnal Gizi Klinik Indonesia. 2006;01:23-31.

13. Endika R. Perbedaan pertambahan panjang badan antara bayi yang menyusui secara ekslusif dan susu formula (skripsi). Surakarta: Fakultas Kedokteran Universitas Sebelas Maret; 2011.
14. Saptawati B. Korelasi antara asupan kalsium dengan indikator tinggi badan. Jurnal Gizi Klinik Indonesia. 2014;01:59-63.

15. Lestari. Pentingnya zat gizi untuk bayi dalam pertumbuhan untuk masa depan yang sehat. Jurnal Kesehatan Ibu dan Anak Indonesia. 2014; 01:52-7. 